\title{
Colonic wall thickness measured by ultrasound: striking differences in patients with cystic fibrosis versus healthy controls
}

\author{
H P Haber, N Benda, G Fitzke, A Lang, M Langenberg, J Riethmüller, M Stern
}

\begin{abstract}
Background-Colonic strictures represent an advanced stage of fibrosing colonopathy in patients with cystic fibrosis.

Aims-To clarify whether ultrasonography can identify patients with an early stage of fibrosing colonopathy and to determine clinical factors that influence bowel wall thickening.

Patients-Ninety patients with cystic fibrosis, median age 10 years, and 46 healthy controls, median age 13 years, were investigated.

Methods-Bowel wall thickness was measured by ultrasound in a prospective study.

Results-In cystic fibrosis, wall thickness of both small intestine and colon was significantly $(p<0.0001)$ higher than in controls; $81 \%$ of patients with cystic fibrosis had a maximum colon wall thickness at any site of $2 \mathrm{~mm}$ or more, a value that was never reached by controls. The maximum colon wall thickness was $6.5 \mathrm{~mm}$. Bowel wall thickness was unchanged at re-examination after one year. There was no progression even with high dose pancreatic supplements. There was no association between bowel wall thickness and clinical features such as previous meconium ileus, intestinal resection, distal intestinal obstruction syndrome, abdominal pain, or pancreatic enzyme dose.
\end{abstract}

Conclusions-There is genuine intestinal involvement in cystic fibrosis; in a few cases this could lead to fibrosing colonopathy.

(Gut 1997; 40: 406-411)

Keywords: cystic fibrosis, bowel wall thickening, ultrasonography, fibrosing colonopathy, colonic stricture.

The gastrointestinal manifestations of cystic fibrosis are characterised by malabsorption leading to steatorrhoea, flatulence, and abdominal pain. In addition to pancreatic insufficiency, small bowel mucosal dysfunction has been recognised as a contributing factor. ${ }^{1}$ Biochemical studies have disclosed dysfunction of the intestinal $\mathrm{Cl}^{-}$transporter, ${ }^{2}$ abnormal secretion of mucus, ${ }^{3}$ and enhanced intestinal uptake of some nutrients (glucose, alanine). ${ }^{4}$ These alterations may account for some of the well known gastrointestinal complications in cystic fibrosis, such as meconium ileus and distal intestinal ob- ڤొ struction syndrome. Among disorders asso- $\overrightarrow{0}$ ciated with cystic fibrosis, Crohn's disease is $17 \overrightarrow{\vec{H}}$ times more common than in the general $\vec{\omega}$ population. $^{5}$

Recently, colonic strictures requiring re- $\stackrel{\stackrel{2}{\risingdotseq}}{=}$ section were described in a series of boys with $\vec{D}$ cystic fibrosis. Subsequently, other cases were $\omega$ added. ${ }^{6-13}$ Although the lesions seemed to be $\vec{\circ}$ related to the introduction of high strength 0 pancreatic enzyme supplements, ${ }^{6}{ }^{14}$ their aetiology remains to be established. Histological $\vec{z}$ features, such as extensive submucosal fibrosis and mild chronic inflammatory infiltrate, do $\frac{\hat{\sigma}}{\supset}$ not resemble previously described strictures, $\overrightarrow{0}$ induced either by ingestion of potassium chloride preparations or non-steroidal antiinflammatory drugs, which are characterised by ulceration. ${ }^{15} 16$

The term "fibrosing colonopathy" was introduced to describe this new type of $\frac{\square}{\square}$ gastrointestinal complication in cystic fibrosis, $\overrightarrow{\vec{A}}$ involving a prestricture state with varying $\frac{0}{3}$ degrees of stenosis, as well as true colonic $\vec{P}$ strictures. ${ }^{17}$ The second can be diagnosed by barium enema, endoscopy, and biopsy. $9131819 \stackrel{0}{0}$ By contrast, the detection of prestricture lesions remains a diagnostic problem, because 3 there are no valid data available on presenting features in these patients, or risk factors for $\frac{3}{3}$ development of colonic strictures.

Recently, we described pronounced colonic wall thickening in a girl with cystic fibrosis $\frac{7}{2}$ detected by ultrasound who had, after meconium ileus, several attacks of distal $\%$ intestinal obstruction syndrome before starting 0 high strength pancreatic enzyme supplementa- స్ tion. ${ }^{20}$ However, at presentation the girl had only few symptoms and the clinical importance 0 of our ultrasound findings remained unclear. It is possible that this bowel wall thickening ? reflected the prestricture state of fibrosing $\frac{0}{0}$ colonopathy.

Participating in a multicentre prospective $\stackrel{\stackrel{\mathbb{D}}{\mathbb{D}}}{\stackrel{\circ}{\circ}}$ study, we investigated a series of patients with $\stackrel{ }{\varrho}$ cystic fibrosis and healthy control subjects. The aim was to evaluate frequency of sono- 8 graphic bowel wall thickening in cystic fibrosis, during clinical evaluation and follow up.

\section{Methods}

\section{Subjects}

In this prospective study, we investigated 90 patients with cystic fibrosis (45 females) with a mean age of 11.9 (SD 9) (median 9.8; range 
TABLE I Associated gastrointestinal problems in the patients with cystic fibrosis $(n=90)$

\begin{tabular}{lc}
\hline & $\begin{array}{l}\text { Patients } \\
n(\%)\end{array}$ \\
\hline Liver disease $^{\star}$ & $20(22)$ \\
Meconium ileus $†$ & $15(17)$ \\
DIOS $\ddagger$ & $11(12)$ \\
Rectal prolapse & $6(7)$ \\
Appendicitis & $5(6)$ \\
Intussusception & $2(2)$ \\
Ulcerative colitis $₫$ & $1(1)$ \\
\hline
\end{tabular}

ॠJudged by the criteria of Colombo et al..$^{35}$

tRequiring resection in 10 cases.

$\ddagger$ Responding to conservative treatment.

fIn remission.

0.4-36) years and 46 healthy controls (22 females) with a mean age of 17 (SD 11.3) (median 13; range 0.4-40) years. Mean weight for height (according to Prader) ${ }^{21}$ was 95 (SD 13) (range 72-149)\%. Informed consent was obtained from subjects and parents. The diagnosis of cystic fibrosis had been confirmed by at least two sweat tests giving chloride values above $60 \mathrm{mmol} / \mathrm{l}$. Eighty six patients had pancreatic insufficiency, documented by increased stool fat excretion before starting enzyme substitution. Table I summarises the history and clinical findings.

Most of the patients with pancreatic insufficiency had been thriving on pancreatic enzyme supplements. Patients with cystic fibrosis were treated with six different pancreatin capsules from two manufacturers: Kreon ${ }^{\circledR} 10000$ and Kreon ${ }^{\circledR} 25000$ (containing 10000 and 25000 lipase units per capsule; Kali Chemie, Hannover, Germany); Panzytrat ${ }^{\circledR}$ 10000 , Panzytrat ${ }^{\circledR} 20000$, Panzytrat ${ }^{\circledR} 25000$, and Panzytrat ${ }^{\circledR} 40000$ (containing 10000 , 20000,25000 , and 40000 lipase units per capsule; Nordmark, Uetersen, Germany). To evaluate the relation between enzyme dosage and bowel wall thickness, patients were divided in three groups: low dose (LD) group $(<5000$ units lipase/kg/day), normal dose (ND) group (5000-15000 units lipase/kg/day), and high dose (HD) group (>15000 units lipase/kg/ day). Duration of enzyme supplementation ranged between 0 and 33 (median 7) years; duration of high dose (HD) treatment ranged between 0 and 7 (median 1.3) years. During the three years before the start of the study, the percentage of the HD group increased from 12 to $35 \%$ (because of raised stool fat excretion on low dosage). The median increment for lipase and protease was $2000 \mathrm{IU} / \mathrm{kg} /$ day and $60 \mathrm{IU} /$ $\mathrm{kg} /$ day, respectively. Table II gives the details for distribution of patients among the different

TABLE II Distribution of patients with cystic fibrosis among the different dosage groups according to lipase content of pancreatin preparations

\begin{tabular}{|c|c|c|c|c|c|}
\hline \multirow[b]{2}{*}{$\begin{array}{l}\text { Dosage } \\
\text { group }\end{array}$} & \multirow[b]{2}{*}{$n$} & \multicolumn{4}{|c|}{$\begin{array}{l}\text { Lipase content (units per capsule) of } \\
\text { pancreatin preparation }\end{array}$} \\
\hline & & $\begin{array}{l}10000 \\
(\%)\end{array}$ & $\begin{array}{l}20000 \\
(\%)\end{array}$ & $\begin{array}{l}25000 \\
(\%)\end{array}$ & $\begin{array}{l}40000 \\
(\%)\end{array}$ \\
\hline $\begin{array}{l}\text { Low } \\
\text { Normal } \\
\text { High }\end{array}$ & $\begin{array}{l}30 \\
29 \\
27\end{array}$ & $\begin{array}{r}74 \\
46 \\
3\end{array}$ & $\begin{array}{r}11 \\
0 \\
4\end{array}$ & $\begin{array}{l}15 \\
50 \\
67\end{array}$ & $\begin{array}{r}0 \\
4 \\
26\end{array}$ \\
\hline
\end{tabular}

dosage groups, and among the different pancreatin preparations.

\section{Ultrasound examination}

The ultrasound examination was done with a $7 \mathrm{MHz}$ linear transducer (Acuson 128, Mountain View, California, USA). Patients were scanned under identical conditions in a supine position about one hour after the last meal. The large intestine was identified by reduced or absent peristalsis and by gas distended bowel located near the right or left kidney (ascending or descending colon), or near the stomach (transverse colon). The caecum was identified as the most proximal part of the ascending colon, where the small intestine enters. The small intestine was identified by pronounced peristalsis located at the upper or lower left of the abdomen (jejunum) or near the right psoas muscle beside the iliacal vessels (ileum). By means of these criteria, the different intestinal segments could be identified in all patients. Identification of the different layers of the bowel wall was in accordance with the characteristics described by Kimmey et al. ${ }^{22}$ The layer next to the lumen is hypoechoic and corresponds to the mucosa (Fig 1). The second layer is the most echogenic layer and corresponds to the submucosa. The next layer is hypoechoic and corresponds to the muscularis propria. The outer layer is echogenic and corresponds to the serosa. Measurement of bowel wall thickness was carried out in true cross sections of the relaxed bowel. Overall thickness of the bowel wall was measured from the first mucosal interface echo to the first serosal echo (Fig 1). Each measurement was repeated three times at different positions of the intestinal wall and the median was calculated. Circumscript narrowing of the bowel lumen was recorded wherever it was seen. In addition, colon peristalsis and occurrence of free peritoneal fluid were recorded. All patients were scanned by one investigator ( $\mathrm{HPH})$, to minimise interobserver variation. The intraobserver coefficient of variation for intestinal ultrasound measurements repeated on consecutive days was $5 \%$. Accuracy of measurement was $0.1 \mathrm{~mm}$.

Re-examination after one year was performed on 72 patients. In the interval, pancreatic enzyme dosage was slightly increased according to stool fat excretion in some patients. The percentage of patients on HD treatment increased from $30 \%$ to $37 \%$.

\section{Clinical evaluation}

Actual episodes of abdominal pain and distension were recorded. The frequency of abdominal pain was graded.

\section{Biological assays}

Occult blood in faeces was recorded (Hemo $\mathrm{Fec}^{\circledR}$; Boehringer, Mannheim, Germany). Stool fat excretion was measured according to the method of van de Kamer et al. ${ }^{23}$ Stool fat 

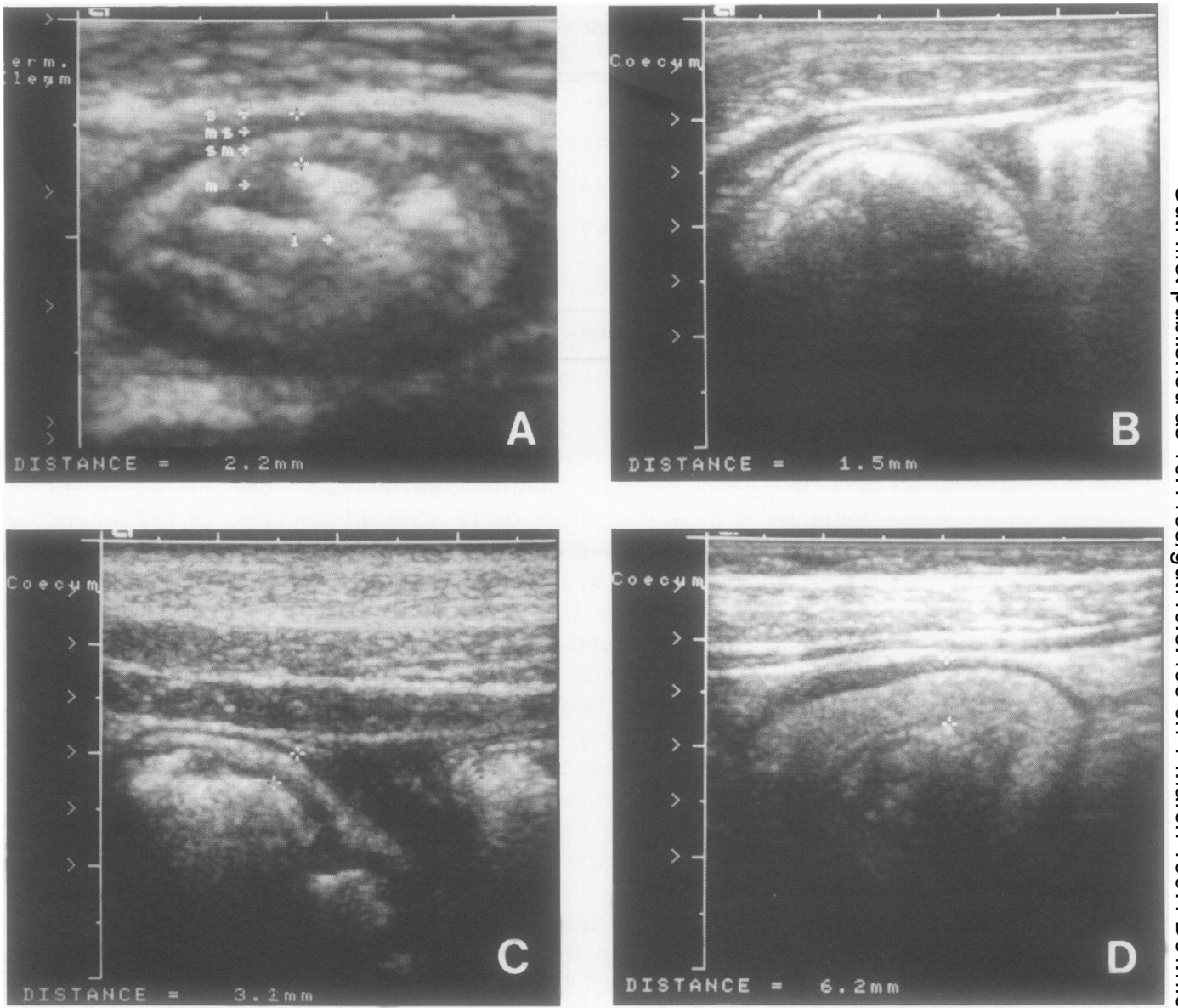

Figure 1: Ultrasound images (cross sections) of bowel wall; (A) scan of the terminal ileum shows the lumen (l) and thickened bowel wall (distance between the two marks, $2 \cdot 2 \mathrm{~mm}$ ). The different layers of the wall correspond to mucosa $(\mathrm{m})$, submucosa (sm), muscularis propria (ms), and serosa (s); (B) normal colon (wall thickness $1.5 \mathrm{~mm}$ ); (C) mild thickening of caecum wall $(3 \cdot 1 \mathrm{~mm}) ;(D)$ pronounced bowel wall thickening of caecum $(6 \cdot 2 \mathrm{~mm})$ with increased thickness of submucosa (echogenic layer).

below $2 \mathrm{~g} /$ day in patients younger than six years of age, and below $7 \mathrm{~g} /$ day in patients older than six years of age was considered normal. ${ }^{24}$ The patients were taking in normal amounts of fat ( $90 \%$ of recommended daily allowance).

\section{Statistics}

Student's $t$ test, multivariate analysis of variance (MANOVA), and multivariate regression were used to analyse the results after logarithmic transformation of bowel wall measurements.

\section{Results}

Table III summarises the ultrasound measurements. In controls, maximum thickness of the wall of the small intestine was $1.5 \mathrm{~mm}$ and maximum thickness of the colon wall was $1.9 \mathrm{~mm}$. There was a slight, but significant $(r=0.594 ; \mathrm{p}<0.001)$ increase with age (Fig 2). In cystic fibrosis, bowel wall thickness of both small intestine and colon was significantly $(\mathrm{p}<0.0001)$ higher than in controls (Fig 3); $81 \%$ of patients with cystic fibrosis had a maximum colon wall thickness at any site of $2 \mathrm{~mm}$ or more, and $46 \%$ of patients had ileum wall thickness of $1.5 \mathrm{~mm}$ or more. Bowel wall thickening of more than $2 \mathrm{~mm}$ involving the entire colon was noted in $19 \%$ of patients. Maximum wall thickness reached $6.5 \mathrm{~mm}$ at the ascending colon in one patient. As in $\frac{0}{3}$ controls, there was a slight but significant $(r=0.193 ; \mathrm{p}<0.001)$ increase in wall thickness with age (Fig 2).

Figure 1 shows representative ultrasound scans of bowel wall thickening of varying o degrees. Bowel wall thickening in cystic fibrosis $N$ was mainly due to increased thickness of $N$ the submucosa, whereas the mucosa and 0 muscularis remained unchanged (Fig 1). $\operatorname{In}_{0}$ cystic fibrosis and in controls there was no peristalsis to disturb colon wall measurements. $\stackrel{?}{+}$ Small amounts of free peritoneal fluid were 0 found in $24(28 \%)$ patients, whereas no fluid $\frac{\vec{D}}{\mathbb{D}}$ was detected in any of the controls.

At re-examination after one year, there was $\stackrel{\unrhd}{\complement}$ no significant change in median wall thickness in 72 of 90 patients, although there was $\delta$ considerable variability in some cases.

None of the patients had significant episodes of abdominal pain or distension. Occasional ? transient abdominal pain was experienced by $53 \%$ of the patients. Occult blood in faeces was detected in none of the patients. On average, excretion of stool fat was $17 \cdot 2$ (range $1 \cdot 1-100$ ) g/day. There was no significant correlation between stool fat excretion and abdominal pain or dosage group. 
TABLE III Bowel wall thickness $(\mathrm{mm})$ in patients with cystic fibrosis $(n=90)$ and controls $(n=46)$ measured by ultrasound

\begin{tabular}{|c|c|c|c|c|c|c|}
\hline & Ileum & Ұеjunum & Caecum & $\begin{array}{l}\text { Ascending } \\
\text { colon }\end{array}$ & $\begin{array}{l}\text { Transverse } \\
\text { colon }\end{array}$ & $\begin{array}{l}\text { Descending } \\
\text { colon }\end{array}$ \\
\hline $\begin{array}{l}\text { Cystic fibrosis: } \\
\text { Mean (SD) } \\
\text { Median } \\
\text { Range }\end{array}$ & $\begin{array}{l}1 \cdot 4(0.5) \\
1.4 \\
0 \cdot 6-3 \cdot 1 \\
\star \star \star \star\end{array}$ & $\begin{array}{l}0.9(0.3) \\
0.9 \\
0.5-2.5 \\
\star \star \star\end{array}$ & $\begin{array}{l}2 \cdot 7(1 \cdot 1) \\
2 \cdot 6 \\
1 \cdot 0-5 \cdot 0 \\
\star \star \star \star\end{array}$ & $\begin{array}{l}2 \cdot 3(1 \cdot 2) \\
2 \cdot 0 \\
0 \cdot 6-6 \cdot 5 \\
\star \star \star \star\end{array}$ & $\begin{array}{l}1 \cdot 8(0 \cdot 7) \\
1.8 \\
0 \cdot 6-4 \cdot 8 \\
\star \star \star \star\end{array}$ & $\begin{array}{l}1 \cdot 7(0 \cdot 8) \\
1.5 \\
0 \cdot 6-6 \cdot 2 \\
\star \star \star \star\end{array}$ \\
\hline $\begin{array}{l}\text { Controls: } \\
\text { Mean (SD) } \\
\text { Median } \\
\text { Range }\end{array}$ & $\begin{array}{l}1.0(0.2) \\
1.0 \\
0.6-1.5\end{array}$ & $\begin{array}{l}0 \cdot 8(0 \cdot 1) \\
0 \cdot 8 \\
0 \cdot 5-1 \cdot 1\end{array}$ & $\begin{array}{l}1.4(0.3) \\
1.3 \\
0.7-1.9\end{array}$ & $\begin{array}{l}1 \cdot 2(0.3) \\
1 \cdot 1 \\
0.6-1.9\end{array}$ & $\begin{array}{l}1 \cdot 1(0 \cdot 3) \\
1 \cdot 1 \\
0 \cdot 6-1 \cdot 8\end{array}$ & $\begin{array}{l}1 \cdot 1(0 \cdot 2) \\
1 \cdot 2 \\
0 \cdot 7-1 \cdot 5\end{array}$ \\
\hline
\end{tabular}

$\star \star \star \mathrm{p}<0.001 ; \star \star \star \star \mathrm{p}<0.0001 v$ controls.

We did not find any association between bowel wall thickening and previous meconium ileus, resection, distal intestinal obstruction syndrome, or abdominal pain. There was, however, a significant $(r=0.261, \mathrm{p}<0.05)$ positive correlation between increased stool fat excretion and increased caecal wall thickness. For pancreatic enzyme supplementation, bowel wall thickness did not correlate with enzyme preparation, protease dose, lipase dose, dosage group, or lifetime dosage (Fig 4).

In the four patients who produced sufficient pancreatic enzyme, maximum wall thickness of the ileum and the colon was $1.4 \mathrm{~mm}$ and $3 \mathrm{~mm}$ respectively. Asymptomatic intussusception was detected in five patients. Two patients with ileoileal intussusception had ileum wall thickness of 1.3 and $1.6 \mathrm{~mm}$; three patients with ileocaecal intussusception had ileum wall thickness between 1.5 and $2 \mathrm{~mm}$ and caecum wall thickness between 3.6 and $3.9 \mathrm{~mm}$.

\section{Discussion}

Ultrasound examination is a widely used noninvasive method for the evaluation of Crohn's disease, ulcerative colitis, and coeliac disease. ${ }^{24-28}$ In recent years, the development of high resolution ultrasound transducers has facilitated identification of the different layers of the bowel wall. Ultrasound examination has

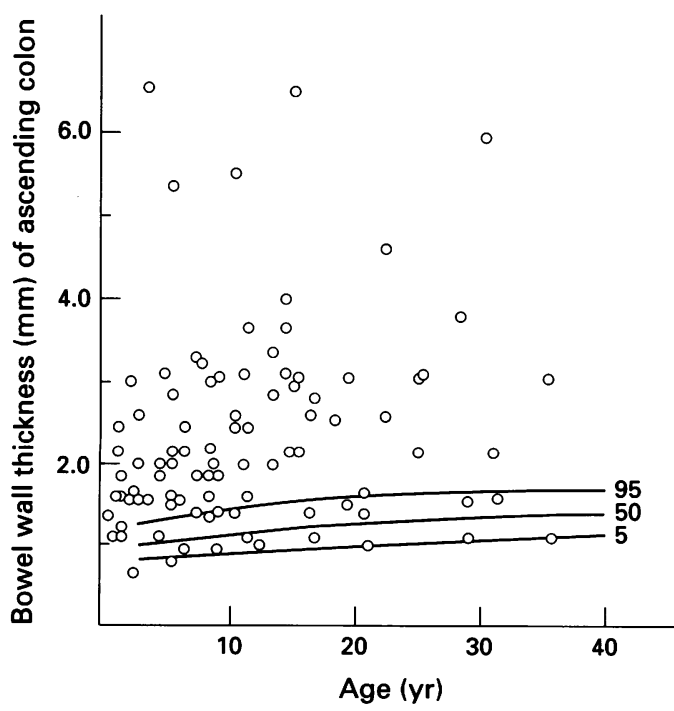

Figure 2: Wall thickness of ascending colon of patients with cystic fibrosis $(n=90)$ according to age. Reference values are estimated as 5\%, 50\%, and 95\% quantiles (lines).

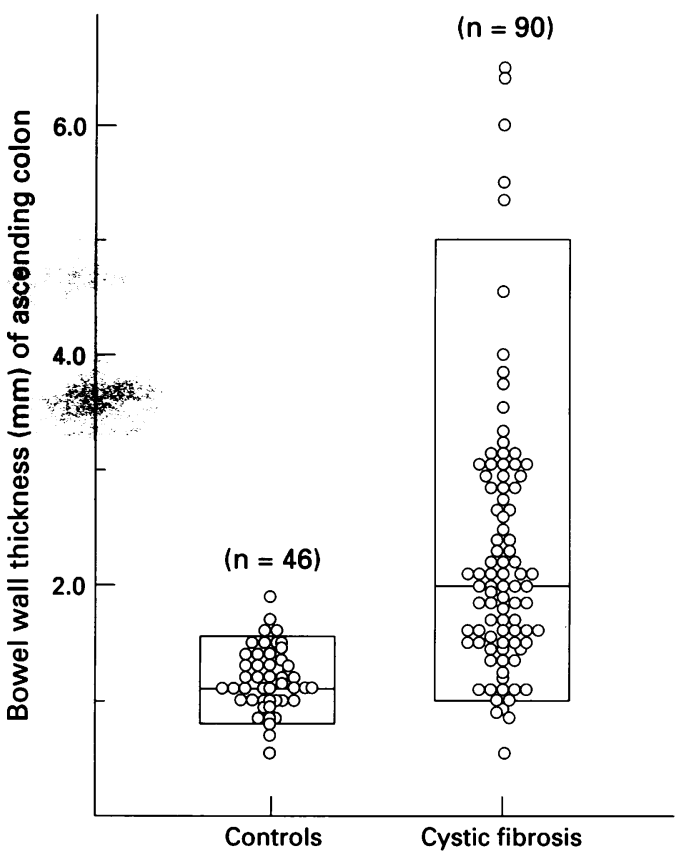

Figure 3: Wall thickness of ascending colon in patients with cystic fibrosis $(n=90)$ and in controls $(n=46)$. Values are expressed as median (horizontal line) and 5\% and $95 \%$ quantiles (box).

therefore provided a means of detecting mucosal changes and bowel wall thickening, and has supplemented conventional diagnostic methods of barium enema and endoscopy. ${ }^{922}$

In the present ultrasound study, we found considerable colonic wall thickening in $81 \%$ of patients with cystic fibrosis. A similar finding was reported by MacSweeney et al ${ }^{14}$ who described colonic wall thickening in $51 \%$ of patients with cystic fibrosis. However, in their study, the maximum colon wall thickness of controls was $0.8 \mathrm{~mm}$. This value differed considerably from our control cut off value of $2.0 \mathrm{~mm}$, and was also much lower compared with earlier studies ( 2 to $3 \mathrm{~mm}) .^{24}$

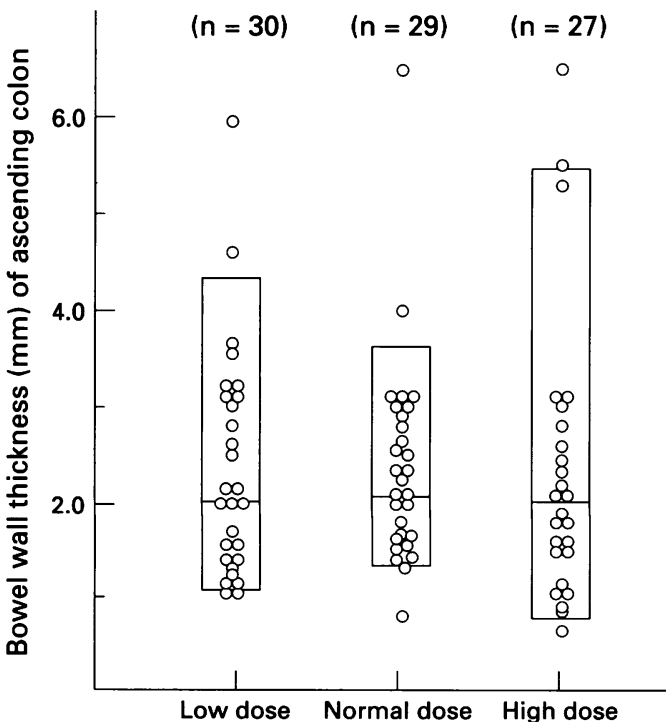

Figure 4: Wall thickness $(\mathrm{mm})$ of ascending colon in patients with cystic fibrosis according to enzyme dosage group. Median and 5\% and $95 \%$ quantiles are indicated by the box and the horizontal bar. Number of patients are given in parentheses. 
Evaluation of the small intestine disclosed ileum wall thickening in $46 \%$ of our patients with cystic fibrosis. It is possible that this may be related to recurrent asymptomatic intussusception, which may occur more often than assumed so far ( $6 \%$ in our series). Terminal ileal involvement (with submucosal fibrosis) was also described in several cases of fibrosing colonopathy. ${ }^{82}{ }^{20}$ In the absence of confirmatory histology, any correlation with our findings remains speculative.

Our ultrasound data showed no correlation between bowel wall thickness and history of meconium ileus or intestinal resection. This confirmed results by MacSweeney et al. ${ }^{14}$ In addition, we could not detect a correlation between bowel wall thickness and previous distal intestinal obstruction syndrome. In the course of our study two patients developed this syndrome, requiring surgical lavage in one. In both cases, the colonic wall was only moderately thickened. These data suggest that distal intestinal obstruction syndrome was not related to bowel wall thickening.

We found an association between increased stool fat excretion and caecal bowel wall thickening. It is well known that, despite appropriate pancreatic supplementation, incomplete control of steatorrhoea occurs in a subgroup of patients with pancreatic enzyme insufficiency. ${ }^{31}{ }^{32}$ The high prevalence of submucosal thickening may be representative of a more extensive intestinal abnormality, which may further affect function. Because our faecal fat studies were only partially accompanied by dietetic evaluation, exact coefficients of fat absorption could not be given.

Despite considerable bowel wall thickening, none of our patients had a major clinical complaint - that is, recurrent abdominal pain, distension, or obstruction. In this regard our patients differed from the group with colonic strictures reported recently, ${ }^{6}$ in whom a common problem was intestinal obstruction requiring surgery. Ultrasonography showed colon wall thickness exceeding $6 \mathrm{~mm}$ in every patient with a stricture (S King, personal communication). In another case report of colonic stricture, colon wall thickness measured by ultrasound was $7 \mathrm{~mm} .{ }^{11}$

In a survey of 114 cystic fibrosis care centres in the United States, surgical pathology reports from 15 patients with colonic strictures were reviewed. ${ }^{33}$ On gross examination, the colonic wall was thickened with luminal narrowing at the stricture site. Histological examination of the resected specimens showed extensive submucosal fibrosis. It was suggested that colonic strictures represent an advanced stage of colonic involvement that was termed "fibrosing colonopathy". ${ }^{17}$ However, the early stage of fibrosing colonopathy is not well characterised. We were able to describe pronounced bowel wall thickening in many asymptomatic patients with cystic fibrosis. Only in one patient was there a circumscript narrowing of the lumen in the ascending colon. Colon wall thickness was $6.5 \mathrm{~mm}$ at this site. However, the child felt well with no sign of bowel obstruction. ${ }^{20}$ During follow up for 10 months, colon wall thickness in this patient decreased gradually to $4.3 \mathrm{~mm}$. We suggest the finding of submucosal thickening in most patients with cystic fibrosis represents a sonomorphological correlate of an early stage of fibrosing colonopathy. However, this has not been determined histologically, and pathological correlation is required to establish an exact correlate.

The rare development of colonic strictures requires separate explanation. Currently it is not known what factors promote transition from early stages to colonic strictures. It has been suggested that high strength pancreatic enzymes are causally related to colonic strictures. ${ }^{6}{ }^{14}$ In a case control study in the United Kingdom cystic fibrosis population, a dose related association between colonic strictures and certain brands of high strength enzyme supplements - in particular, Nutrizym $22^{\circledast}$ and Pancrease $\mathrm{HL}^{\circledast}$ - or laxative usage was found. ${ }^{34}$ By contrast, for the high strength preparation Creon ${ }^{\circledast} 25000$, no association could be detected. However, only eight of 15 patients with colonic strictures reviewed in the United States survey were on high strength pancreatic supplementation..$^{33}$ In the present study, we could not detect a correlation between bowel wall thickness and actual or lifetime enzyme dosage, or preparation. Bowel wall thickening was unchanged in most patients at re-examination after one year despite the dosage not being reduced. Thus there is no direct evidence that pancreatic enzymes played a major part in the pathogenesis of fibrosing colonopathy.

We conclude that submucosal bowel wall thickening is a common feature in patients with cystic fibrosis, which seems unrelated to various clinical factors and supplementation. Ultrasound examination was a reliable noninvasive method for evaluating this intestinal involvement in cystic fibrosis. As pancreatic enzyme dosage was obviously not correlated with bowel wall thickening, recommendations on changes in pancreatic supplementation seem premature. Further studies are necessary $\stackrel{N}{\circ}$ to determine the natural history of fibrosing $\sim$ colonopathy and to detect risk factors for $\underset{\mathrm{W}}{\mathrm{W}}$ colonic strictures. Until these are understood, פ it would seem unnecessary to harm patients by inducing steatorrhoea with insufficient pancreatic supplementation.

This work was presented in part at the 20th European Cystic Fibrosis Conference (EWGCF), Brussels, 20 June 1995.

1 Eggermont E, De Boeck K. Small-intestinal abnormalities in patients with cystic fibrosis. Eur $\mathcal{F}$ Pediatr 1991; 150: 824-8.

2 De Jonge HR. The molecular basis of chloride channel dysregulation in cystic fibrosis. Acta Paediatr Scand dysregulation in cystic

3 Weslo A Forser JF, Qureshi R Mantle M, Forstner GG. Wesley A, Forstner JF, Qureshi R, Mante M, Forstner GG. Human intestinal

4 Baxter R, Goldhill J, Hardcastle J, Hardcastle PT, Taylor CJ. Enhanced intestinal glucose and alanine transport in cystic fibrosis. Gut 1990; 31: 817-20.

5 Lloyd-Still JD. Crohn's disease and cystic fibrosis. Dig Dis Sci 1994; 39: 880-5.

6 Smyth RL, vanVelzen D, Smyth AR, Lloyd DA, Heaf DP. Strictures of ascending colon in cystic fibrosis and highstrength pancreatic enzymes. Lancet 1994; 343: 85-6. 
7 Oades PJ, Bush A, Ong PS, Brereton RJ. High-strength pancreatic enzyme supplements and large-bowel stricture pancreatic enzyme supplements and large-t

8 Campbell CA, Forrest J, Musgrove C. High-strength pancreatic enzyme supplements and large-bowel stricture in cystic fibrosis. Lancet 1994; 343: 109.

9 Taylor CJ, Dodge JA. High-strength pancreatic enzyme supplements and large-bowel stricture in cystic fibrosis. Lancet 1994; 343: 110 .

10 Mahony MJ, Corcoran M. High-strength pancreatic enzymes. Lancet 1994; 343: 599.

11 Ong PS, Oades PJ, Bush A, Brereton RJ. Colonic stricture in a boy with cystic fibrosis. Postgrad Med $\mathcal{F} 1995 ; 71$ : 309-12.

12 Green MR, Southern KW, Wolfe SP, Littlewood JM. Colonic strictures in cystic fibrosis. Arch Dis Child 1995 72: 191 .

13 Prestridge L, Rogers BB, Pritchard M, Hermann D Megison S, Brown ME, et al. Diffuse fibrosis of the colon complicating cystic fibrosis. 7 Pediatr Gastroenterol Nutr 1996; 22: 219-24.

14 MacSweeney E, Oades PJ, Buchdahl RM, Phelan M Bush A. Relationship of thickening of colon wall to pancreatic enzyme treatment in cystic fibrosis. Lancet pancreatic enzyme

15 Baker DR, Schrader H, Hitchcock CR. Small bowel ulceration apparently associated with thiazide and potassium therapy. $\mathscr{f} A M A 1964 ; 190: 134-8$.

16 Halter F, Weber B, Huber T, Eigenmann F, Frey MP, Ruchti C. Diaphragm disease of the ascending colon. Association with sustained-release diclofenac. $\mathcal{f}$ Clin Gastroenterol 1993; 16: 74-80.

17 Borowitz DS, Grand RJ, Durie PR. Use of pancreatic enzyme supplements for patients with cystic fibrosis in the enzyme supplements for patients with cystic fibrosis in the
context of fibrosing colonopathy. $¥$ Pediatr 1995; 127: context

18 Zerin JM, Kuhn-Fulton J, White SJ, Chong SKF, Stevens $\mathrm{JC}$, West KW, et al. Colonic strictures in children with cystic fibrosis. Radiology 1995; 194: 223-6.

19 Carty H. Abdominal radiology in cystic fibrosis. $f(R$ Soc Med 1995; 88 (suppl): 18-23.

20 Haber HP, Lang A, Drews K, Stern M. Colonic wall thickening in cystic fibrosis identified by ultrasound. $\mathcal{f}$ Pediatr Gastroenterol Nutr 1996; 23: 487-91.

21 Prader A. Normales Wachstum und Wachstumsstörungen bei Kindern und Jugendlichen. Klin Wochenschr 198; 59: 977-84.
22 Kimmey MB, Martin RW, Haggitt RC, Wang KY, Franklin $\mathrm{DW}$, Silverstein FE. Histologic correlates of gastrointestinal ultrasound images. Gastroenterology 1989; 96: intestinal

23 Van de Kamer J, Ten Bokkel Huinink H, Weijers H. A rapid method for the determination of fat in feces. $\mathcal{F}$ Biol Chem 1949; 177: 347-55.

24 Worlicek H, Lutz H, Heyder N, Matek W. Ultrasound findings in Crohn's disease and ulcerative colitis: a prospective study. $\mathcal{F}$ Clin Ultrasound 1987; 15: 153-63.

25 Limberg B. Diagnosis of acute ulcerative colitis and colonic Crohn's disease by colonic sonography. $¥$ Clin Ultrasound Crohn's disease by

26 Kimmey MB, Wang KY, Haggitt RC, Mack LA, Silverstein FE. Diagnosis of inflammatory bowel disease with ultrasound. Invest Radiol 1990; 25: 1085-90.

27 Hata J, Haruma K, Suenaga K, et al. Ultrasonographic assessment of inflammatory bowel disease. Am $\mathcal{F}$ Gastroenterol 1992; 87: 443-7.

28 Riccabona M, Rossipal E. Sonographic findings in celiac disease. 7 Pediatr Gastroenterol Nutr 1993; 17: 198-200.

29 Taylor CJ, Steiner GM. Fibrosing colonopathy in a child on low-dose pancreatin. Lancet 1995; 346: 1106-7.

30 Jones R, Franklin K, Spicer R, Berry J. Colonic strictures in children with cystic fibrosis on low-strength pancreatic enzymes. Lancet 1995; 346: 499.

31 Guarner L, Rodinguez R, Guarner F, Malagelada JR. Fate of oral enzymes in pancreatic insufficiency. Gut 1993; 34: 708-12.

32 Regele S, Henker J, Münch R, Barbier Y, Stern M. Indirect parameters of pancreatic function in cystic fibrosis (CF) during a controlled double-blind trial of pancreatic supplementation. $\mathcal{F}$ Pediatr Gastroenterol Nutr 1996; 22: supplemer 68 .

33 Freimann JP, FitzSimmons SC. Colonic strictures in patients with cystic fibrosis: Results of a survey of 114 cystic fibrosis care centers in the United States. $\mathcal{F}$ Pediat Gastroenterol Nutr 1996; 22: 153-6.

34 Smyth RL, Ashby D, O'Hea U, Burrows E, Lewis P, Van Velzen D, Dodge JA. Fibrosing colonopathy in cystic fibrosis: results of a case-control study. Lancet 1995; 346: 1247-51.

35 Colombo C, Apostolo MG, Ferrari M, Seia M, Genoni S, Giunta A, et al. Analysis of risk factors for the development of liver disease associated with cystic fibrosis. $\mathcal{F}$ Pediatr 1994; 124: 393-9. 